\title{
The relationship between fecal incontinence and vaginal delivery in the postmenopausal stage
}

\section{Postmenopozal dönemde görülen fekal inkontinansların vajinal doğumla ilişkisi}

\author{
Süleyman Kargın¹, Sami Çifçi², Adnan Kaynak³, Hüseyin Atasevenn ${ }^{4}$, Cengiz Kadıyoran5, Murat Çakır³ \\ ${ }^{1}$ Medova Private Hospital, Clinic of General Surgery, Konya, Turkey \\ ${ }^{2}$ Karaman State Hospital, Clinic of Gastroenterology, Karaman, Turkey \\ ${ }^{3}$ Necmettin Erbakan University Meram Faculty of Medicine, Department of General Surgery, Konya, Turkey \\ ${ }^{4}$ Necmettin Erbakan University Meram Faculty of Medicine, Department of Gastroenterology, Konya, Turkey \\ 5 Medova Private Hospital, Clinic of Radiology, Konya, Turkey
}

\begin{abstract}
Objective: Obstetric anal sphincter injuries are one of the most significant complications of vaginal delivery that give way to fecal incontinence, which is defined as the involuntary leakage of gas, fluid or solid stool. Although sphincter injuries are seen in 0.5-9\% of all deliveries. It has been reported that 20$41 \%$ of women who had vaginal deliveries had occult anal sphincter injuries as endoanal ultrasonography began to be used by physicians. The aim of our study was to investigate the relationship between fecal incontinence, whose incidence increases dramatically during the postmenopausal stage, and occult anal sphincter injuries.

Materials and Methods: Two hundred healthy female patients with no history of anal sphincter injury, aged between 18 and 70 years were included in the study. The participants were divided into 4 groups according to their menopausal stages and mode of delivery; premenopausal (group 1) and postmenopausal (group 2) vaginal delivery, and premenopausal (group 3) and postmenopausal (group 4) cesarean section. Wexner incontinence scores were determined. The participants' defects were assessed using endoanal ultrasound and their status of fecal incontinence using anorectal manometric measurements.

Results: Anorectal manometric measurement results were found significantly lower in group 1 than in group 3 (p<0.01). The Wexner scores of groups 1 and 3 were similar. The anorectal manometric measurement results of group 2 were significantly lower than those of group 4 , and the Wexner score of group 2 was significantly higher than other groups ( $\mathrm{p}=0.03$ ).

Conclusion: Anal sphincter injuries formed after vaginal delivery may be one of the reasons that increase the incidence of postmenopausal fecal incontinence and cause the formation of fecal incontinence symptoms in women.
\end{abstract}

Keywords: Fecal incontinence, obstetric sphincter injury, postmenopausal stage

$\ddot{\mathrm{O} z}$

Amaç: Obstetrik anal sfinkter yaralanmaları vajinal doğumların önemli bir komplikasyonudur ve istemsiz gaz, sıvı veya katı gaita kaçă̆ı olarak tanımlanan fekal inkontinanslara neden olmaktadırlar. Tüm doğumların \%0,5-9'unda sfinkter yaralanması görülmesine rağmen endoanal ultrasonografinin kullanıma girmesiyle vajinal doğum yapmış kadınların \%20-4l’inde okült anal sfinkter yaralanmaları olduğu tespit edilmiştir. Çalışmamızın amacı postmenapozal dönemde insidansı dramatik artan fekal inkontinansların okült anal sfinkter yaralanmaları ile ilişkisinin incelenmesidir.

Gereç ve Yöntemler: Anal sfinkter yaralanması öyküsü olmayan 18-70 yaş arası 200 sağlıklı kadın çalışmaya alındı. Katılımcılar premenapozal ve postmenapozal vajinal doğum; premenapozal ve postmenaozal sezaryenle doğum yapanlar olmak üzere 4 gruba ayrıldı. Katılımcllar menapoz durumu ve doğum türüne göre 4 gruba ayrıldı. Wexner inkontinans skorlanı belirlendi. Katılımcıların anal sfinkter defektleri endoanal ultrason ile anal sfinkter fonksiyonları ise anorektal manometer ile değerlendirildi.

Bulgular: Grup l'de anorektal manometre ölçüm değerleri grup 3'ten anlamlı olarak daha düşük bulundu (p<0,01). Grup 1 ve grup 3 arasında Wexner skoru benzerdi. Grup 2'nin anorektal manometrik ölçüm değerleri grup 4'ten anlamlı olarak daha düşüktü. Wexner skoru ise grup 2'de anlamlı olarak daha yüksekti $(\mathrm{p}=0,03)$.

Sonuç: Vajinal doğum sonrası oluşan anal sfinkter yaralanmaları kadınlarda menapoz sonrası fekal inkontinansların insidansının artmasına ve fekal inkontinans semptomların oluşmasına neden olan bir faktör olabilir.

Anahtar Kelimeler: Fekal inkontinans, obstetrik sfinkter yaralanması, postmenapozal durum

Address for Correspondence/Yazıșma Adresi: Süleyman Kargın, MD,

Medova Private Hospital, Clinic of General Surgery, Konya, Turkey

Phone: +903322230500 E-mail: drs.kargin@hotmail.com

Received/Geliș Tarihi: 10.11.2016 Accepted/Kabul Tarihi: 04.01.2017

${ }^{\oplus}$ Copyright 2017 by Turkish Society of Obstetrics and Gynecology

Turkish Journal of Obstetrics and Gynecology published by Galenos Publishing House. 


\section{Introduction}

Obstetric anal sphincter injuries (OASIS) account for a significant complication of vaginal deliveries and cause fecal incontinence (FI), which is defined as the involuntary leakage of gas, fluid or solid stool(1). They are seen in $0.5-9 \%$ of all deliveries(2). Post-delivery FI incidence, however, is about 3\%(3). Only 30\% of patients with OASIS were observed to have FI symptoms a year after delivery(4). It has also been reported that rates of fecal emergency and FI in the geriatric population reaches up to $53-80 \%(5)$.

As endosonography became more common, occult anal sphincter injuries were detected in most of women with FI. Moreover, it has been shown that 20-41\% of women who had normal deliveries but were without FI symptoms had ongoing occult anal sphincter injuries(6). Although there have been ample studies on occult anal sphincter injuries within the last decade, its clinical significance and natural history are still unclear(7). Further, it has also been argued that these injuries might become symptomatic at later ages(8). The reason for the increase seen in FI prevalence in women at later ages is controversial. It has been suggested that the existence of estrogen and progesterone receptors in women led to an increase in FI in the postmenopausal stage because of their hormonal effects on sphincters and pelvic floor muscles $(9)$ but this correlation still proves to be controversial $(10,11)$.

We believe that occult anal sphincter injuries following delivery become symptomatic with changes seen in the postmenopausal stage. Therefore, our aim in this study was to investigate whether occult anal sphincter injuries are among the causes of postmenopausal FIs.

\section{Materials and Methods}

Before the study was initiated, the consent of Necmettin Erbakan University, Meram Faculty of Medicine's Board of Ethics for Clinical Trials was obtained (approval number: 2013/79). Healthy women who presented to the gynecology outpatient clinics of Necmettin Erbakan University Meram Faculty of Medicine between May 2013 and November 2013 with a history of delivery but with no previous history of anal sphincter injury were included in the study. Women aged between 18 and 70 years with at least one delivery and a 6-month interval after their latest delivery were covered by the study. Patients who had been clinically diagnosed as having sphincter injuries and subsequently received treatment for these injuries, and women aged over 70 years were excluded from the study because they were thought to be unsuitable for the tests required. All participants who had vaginal deliveries had a mediolateral episiotomy story at the first birth. Participants who underwent multiple episiotomies or did not have episiotomy were not included in the study. The criteria for inclusion and exclusion in the study are shown in Table 1.

Informed consents were obtained from all participants and they were allocated into 4 groups according to their mode of delivery and menopausal status. Each group had 50 participants, a total of 200 for the whole study. Sample size was set at a minimum of 46 participants for each group with a margin of error of $\alpha=0.05$ and $\beta=0.20$ as revealed by the power analysis performed based on study data presented by Donnelly et al.(12).

\section{Groups}

Group 1: Premenopausal women with a history of vaginal delivery,

Table 1. The study inclusion and exclusion criteria

Criteria for inclusion

- Aged between 18 and 70 years

- At least one delivery at the expected delivery time

- At least 6-month interval from the latest delivery for subjects with recent history of delivery

- Less than one episiotomy at vaginal delivery

\section{Criteria for exclusion}

- Previous history of anorectal or vaginal surgical procedure

- Diabetes

- Chronic constipation

- History of neurologic disease

- Pelvic organ prolapsus

- Inflammatory intestinal diseases

- Stage 3 or 4 sphincter injury during vaginal delivery

- Complicated delivery

- Macrosomia

- Fetal growth retardation

- Fetal malformation

- Oligohydramnios

- Polyhydramnios

- Existence of malignancy

- Pregnancy

- Other major health issues

- Multiple episiotomies at vaginal delivery

- No episiotomy at vaginal delivery 
Group 2: Postmenopausal women with a history of vaginal delivery,

Group 3: Premenopausal women with a history of c-section (premenopausal control group),

Group 4: Postmenopausal women with a history of c-section (postmenopausal control group).

Premenopausal period: Women aged between 18 and 49 years with at least one delivery and who menstruated at least once in the last 12 months.

Postmenopausal period: Women aged between 49 and 70 years who had no history of menstruation in the last 12 months.

\section{Evaluation of participants}

The age, mode of delivery, number of deliveries, history of postpartum clinical anal sphincter, history of anal sphincter repair, and whether the patients had had symptoms of postpartum FI were questioned. FI scoring was conducted according to the 20-point Wexner incontinence scale (WIS), which is based on patients' gas, fluid, solid incontinence status and designed to determine changes in lifestyle and the frequency of the need to use pads.

\section{Anorectal manometric measurement}

All subjects received rectum cleansing with a fleet enema before the examination. The subjects were evaluated in the left lateral decubitus position. A Peritron precision perineometer 9300AV (Cardio Design Pty Ltd, Oakleigh, Victoria, Australia) perineometer and 3010 (Cardio Design Pty Ltd, Oakleigh, Victoria, Australia) type anal sensor were used.

The anal probe was $80 \mathrm{~mm}$ in length and was produced to have a pressure-sensitive part of $30 \mathrm{~mm}$ in the middle. The average figure for serial measurements of 1 minute anal channel resting pressure of the subjects was recorded. The subjects were then told to contract the anal sensor as powerfully as they could and to hold it in contraction. This procedure was repeated 3 times with 10 second intervals and the data were recorded. The values with the most successful contraction were determined to be the manometric values of the subject(13). Maximum contraction pressure values were taken into consideration in the evaluation of the subjects' external anal sphincter (EAS) contractions. The pressure unit

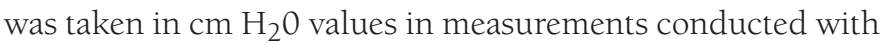
the perineometer.

\section{Endoanal ultrasonography}

The anal endosonography procedure was performed at the imaging laboratory of our hospital's gastroenterology clinic. Imaging was conducted using a Fujinon ITD-01 EUS and a P2612M model flexible radial ultrasonic sonoprobe with $12 \mathrm{MHz}$ frequency. All endoanal ultrasonography (EAUSG) procedures were performed by two physicians experienced in gastroenterology and proctology. The participants' information about their mode of delivery was not shared with the physician performing EAUSG. The locations of all defects [OASIS and/or internal anal sphincter (IAS)] were located.

\section{Statistical Analysis}

The mean, standard deviation, lowest, highest median, frequency, and percentage rates were used in the descriptive statistics of the collected data. The distribution of variables was measured using the Kolmogorov-Smirnov test. The MannWhitney U test was used for the analysis of quantitative data, and the chi-square test was used for the analysis of qualitative data. The effect level was investigated by univariate and multivariate logistic regression. SPSS 22.0 was used for all analyses.

\section{Results}

The demographic data of the premenopausal (group $1+$ group 3 ) and postmenopausal (group $2+$ group 4) groups are shown in Table 2. The episiotomies in vaginal deliveries were all mediolateral. There were no statistical differences between the groups regarding the participants' body mass index (BMI), high birth weight, and instrument use ( $p>0.51$ ).

The mean age and the number of deliveries of the patients in group 1 were similar to those of group 3 . The endoanal ultrasonography imaging revealed that $20(40 \%)$ and $2(4 \%)$ patients in groups 1 and 3 had occult anal sphincter defects, respectively. Although sphincter defects were mostly seen in the EAS (24\%) in group 1 , only 2 patients were detected as having IAS defects in group 3 (Table 3). Anorectal manometric measurements showed that the maximum extrusion pressure, mean extrusion duration, and mean extrusion pressure values of group 1 were significantly lower than group 3 [odds ratio (OR): 1.02, 95\% confidence interval (CI): 1.01-1.039; OR: 1.04, 95\% CI: 1.02-1.05; OR: 1.03, 95\% CI: 1.02-1.05; $\mathrm{p}<0.01$, respectively). There was no significant difference ( $p>0.05$ ) between group 1 and group 3 regarding WIS and the mean resting pressure values (Table 4 ).

There was no difference between group 2 and group 4 with regards to the mean age of the patients and the number of deliveries. Twenty-two (44\%) patients in group 2 were detected to have occult anal sphincter defects according to endoanal ultrasonography data, and $2(4 \%)$ patients in group 4 had sphincter defects $(\mathrm{p}<0.001)$. The most common sphincter defect seen in group 2 was EAS (24\%). Anorectal manometric measurements showed that the maximum extrusion pressure, mean extrusion duration, mean extrusion pressure values of group 2 were significantly lower than group 4 (1.025 OR, 95\% CI:0,46-0,78; $\mathrm{p}<0.001$ ). There was, however, no significant difference between the groups regarding the mean resting pressure. The Wexner score of group 2 was significantly higher than group 4 (0.64 OR, 95\% CI:[0.480.86]; $\mathrm{p}=0.003)$. Although 8 (16\%) of patients had distinctive FI and $14(28 \%)$ had incontinence symptoms in group 2, $10(20 \%)$ patients had started to have fecal complaints in group 4 (Table 5). When the patients who had had vaginal delivery were compared with regards to their menopausal status, there were no statistical differences between the groups according to EAUSG data with regards to the existence of sphincter defects and the location of defects ( $p=0.68$ ). Anorectal manometric measurements showed that the maximum extrusion pressure, mean extrusion duration, 
mean extrusion pressure values of group 2 were significantly lower than group $1(\mathrm{p}<0.05)$. The Wexner scores of the groups were not significantly different (Table 6). Although no obvious FI was observed in group 1, 7 (14\%) patients in group 2 had obvious FI. Figure 1 graphically demonstrates maximum contrusion pressures, WIS, mean contrusion durations, and mean contrusion pressure values of all groups.

\section{Discussion}

One of the most significant causes of FI in women is vaginal deliveries that result in anal sphincter injuries. Although
OASIS is seen in $0.5-9 \%$ of all deliveries, it has been reported that $35-44 \%$ of women who had vaginal deliveries also had occult anal sphincter injuries when EAUSG began to be used by physicians $(6)$. However, FI symptoms are observed in only $20 \%$ of these women. Therefore, the natural history and significance of occult anal sphincter injuries still proves to be controversial(14). In our study, we investigated the effects of occult anal sphincter injuries formed after vaginal deliveries on FI seen in the postmenopausal stage. Factors such as the number of deliveries, which increase the risk of FI after vaginal delivery, use of vacuum and forceps during delivery, BMI,

Table 2. Demographic data of the participants according to premenopausal and postmenopausal stages

\begin{tabular}{|c|c|c|c|}
\hline \multirow[t]{3}{*}{ Demographic data } & $\begin{array}{l}\text { Premenopausal group } \\
\text { (group } 1+\text { group } 3 \text { ) }\end{array}$ & $\begin{array}{l}\text { Postmenopausal group } \\
\text { (group } 2+\text { group } 4 \text { ) }\end{array}$ & $\mathrm{p}$ \\
\hline & Mean \pm SD & Mean \pm SD & \\
\hline & Min - Max & Min - Max & \\
\hline \multirow[t]{2}{*}{ Age } & $36.66 \pm 6.44$ & $55.68 \pm 5.49$ & $>0.001$ \\
\hline & $21-48$ & $49-70$ & \\
\hline \multirow[t]{2}{*}{ Delivery number } & $2.52 \pm 1.15$ & $3.18 \pm 1.81$ & 0.060 \\
\hline & $1-6$ & $1-11$ & \\
\hline Wexner score & $1.08 \pm 1.84$ & $1.14 \pm 2.05$ & 0.828 \\
\hline \multirow{2}{*}{ Maximum contraction pressure $\mathrm{cm} \mathrm{H}_{2} \mathrm{O}$} & $187.66 \pm 51.30$ & $161.70 \pm 50.44$ & $<0.001$ \\
\hline & $90.90-290.30$ & $56.50-264.90$ & \\
\hline \multirow[t]{2}{*}{ Time/second } & $65.31 \pm 39.14$ & $54.80 \pm 30.14$ & 0.035 \\
\hline & 10-194.29 & $5-147.8$ & \\
\hline \multirow[t]{2}{*}{ Average contraction pressure $\mathrm{cm} \mathrm{H}_{2} \mathrm{O}$} & $120.83 \pm 38.11$ & $118.17 \pm 43.77$ & 0.647 \\
\hline & $40.20-211.60$ & $25.40-217.20$ & \\
\hline \multirow[t]{2}{*}{ Gradient } & $42.33 \pm 47.17$ & $40.31 \pm 41.75$ & 0.748 \\
\hline & $0.70-223.6$ & $2.20-220$ & \\
\hline
\end{tabular}

SD: Standard deviation, Min: Minimum, Max: Maximum

Table 3. Endoanal ultrasound data of participants that location and size of defect at all groups

\begin{tabular}{|c|c|c|c|c|c|}
\hline & Location & $\begin{array}{l}\text { No defect } \\
\text { n (\%) }\end{array}$ & $\begin{array}{l}<90^{\circ} \\
\text { n (\%) }\end{array}$ & $\begin{array}{l}90-180^{\circ} \\
\text { n (\%) }\end{array}$ & $\begin{array}{l}<180^{\circ} \\
\text { n (\%) }\end{array}$ \\
\hline Group 1 & $\begin{array}{l}\text { IAS } \\
\text { EAS } \\
\text { IAS + EAS }\end{array}$ & $30(60)$ & $\begin{array}{l}- \\
7(14) \\
5(10)\end{array}$ & $\begin{array}{l}2(4) \\
4(8) \\
1(2)\end{array}$ & $\begin{array}{l}- \\
1(2) \\
-\end{array}$ \\
\hline Group 2 & $\begin{array}{l}\text { IAS } \\
\text { EAS } \\
\text { IAS + EAS }\end{array}$ & $28(56)$ & $\begin{array}{l}2(4) \\
10(20) \\
6(12)\end{array}$ & $\begin{array}{l}1(2) \\
1(2) \\
-\end{array}$ & $\begin{array}{l}1(2) \\
1(2) \\
-\end{array}$ \\
\hline Group 3 & $\begin{array}{l}\text { IAS } \\
\text { EAS } \\
\text { IAS + EAS }\end{array}$ & $48(56)$ & $\begin{array}{l}2(4) \\
- \\
-\end{array}$ & $\begin{array}{l}- \\
- \\
-\end{array}$ & $\begin{array}{l}- \\
- \\
-\end{array}$ \\
\hline Group 4 & $\begin{array}{l}\text { IAS } \\
\text { EAS } \\
\text { IAS + EAS }\end{array}$ & $48(56)$ & $\begin{array}{l}2(4) \\
- \\
-\end{array}$ & $\begin{array}{l}- \\
- \\
-\end{array}$ & $\begin{array}{l}- \\
- \\
-\end{array}$ \\
\hline
\end{tabular}

IAS: Internal anal sphincter, EAS: External anal sphincter 


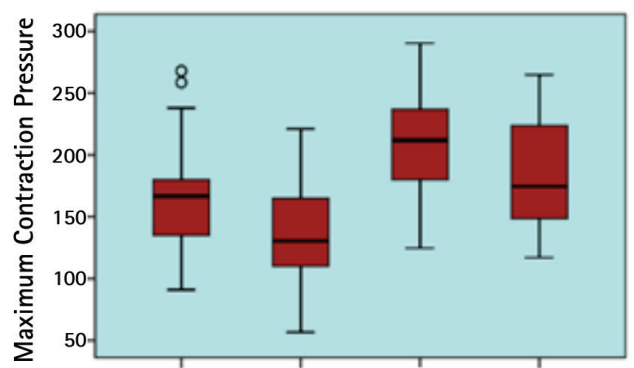

Group 1 Group 2 Group 3 Group 4

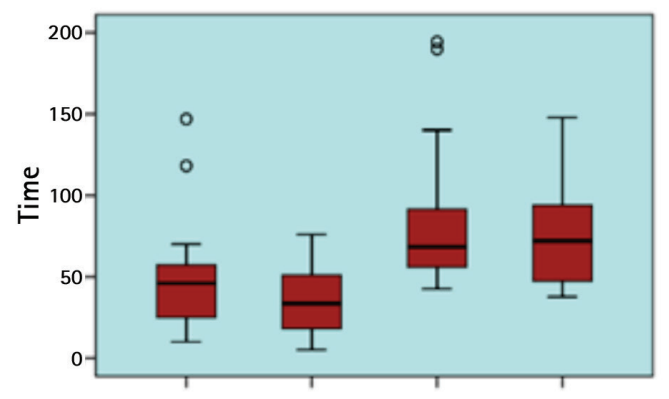

Group 1 Group 2 Group 3 Group 4

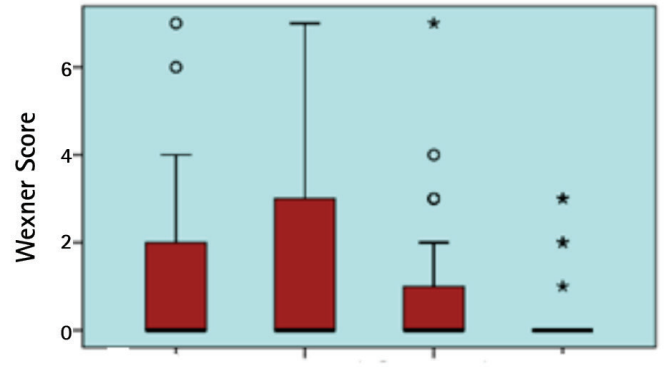

Group 1 Group 2 Group 3 Group 4

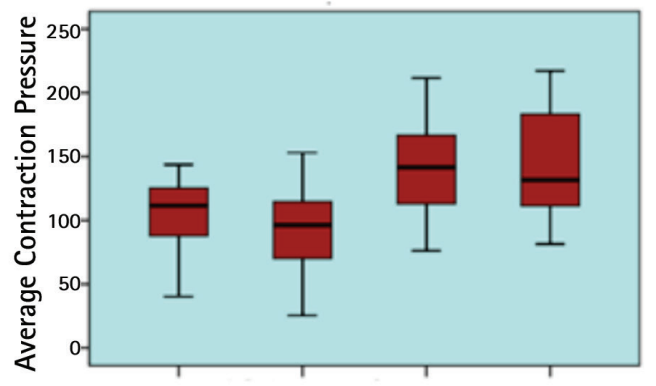

Group 1 Group 2 Group 3 Group 4

Figure 1. The distribution of maximum contrusion pressure, Wexner incontinence scale, mean contraction duration, and mean contraction pressure values of the participants according to the groups

Table 4. The comparison of demographic data, endoanal ultrasonography, and manometric measurement results of groups 1 and 3

\begin{tabular}{|c|c|c|c|c|c|c|c|c|c|c|}
\hline & & \multicolumn{4}{|c|}{ Group 1} & \multicolumn{4}{|c|}{ Group 3} & \multirow{2}{*}{$\mathrm{p}$} \\
\hline & & Mean \pm SD & n (\%) & Med & (Min - Max) & Mean \pm SD & n (\%) & Med & (Min - Max) & \\
\hline \multicolumn{2}{|l|}{ Age } & $38.0 \pm 6.2$ & & 38 & $21-48$ & $37.3 \pm 6.4$ & & 36 & $25-48$ & 0.154 \\
\hline \multicolumn{2}{|c|}{ Delivery number } & $2.5 \pm 1.4$ & & 3 & $1-6$ & $2.3 \pm 0.8$ & & 2 & $1-4$ & 0.064 \\
\hline \multicolumn{2}{|c|}{ Wexner score } & $1.3 \pm 2.0$ & & 0 & $0-7$ & $0.8 \pm 1.7$ & & 0 & $0-7$ & 0.112 \\
\hline & 0 & 28 & $56 \%$ & & & 36 & $72 \%$ & & & \\
\hline & $1-3$ & 16 & $32 \%$ & & & 10 & $20 \%$ & & & \\
\hline & $4-5$ & 2 & $4 \%$ & & & 2 & $4 \%$ & & & \\
\hline & $>6$ & 4 & $8 \%$ & & & 2 & $4 \%$ & & & \\
\hline \multicolumn{2}{|l|}{$\mathrm{RP}$} & $53.1 \pm 20.7$ & & 52 & $23-95$ & $53.8 \pm 12.5$ & & 52 & $33-77$ & 0.912 \\
\hline \multicolumn{2}{|l|}{$\mathrm{MCP}$} & $163.8 \pm 46.6$ & & 167 & $91-268$ & $211.5 \pm 44.5$ & & 212 & $125-290$ & $<0.001$ \\
\hline \multicolumn{2}{|l|}{ Time } & $48.6 \pm 30.8$ & & 46 & $10-147$ & $82.0 \pm 39.7$ & & 68 & 43-194 & $<0.001$ \\
\hline \multicolumn{2}{|l|}{$\mathrm{ACP}$} & $103.0 \pm 29.9$ & & 112 & $40-144$ & $138.6 \pm 37.4$ & & 141 & $76-212$ & $<0.001$ \\
\hline \multicolumn{2}{|c|}{ Gradient } & $33.4 \pm 40.1$ & & 15 & $1-153$ & $51.3 \pm 52.2$ & & 30 & $3-224$ & 0.003 \\
\hline \multirow{6}{*}{ Defect } & No & 30 & $60 \%$ & & & 48 & $96 \%$ & & & \multirow{2}{*}{$<0.001$} \\
\hline & Yes & 20 & $40 \%$ & & & 2 & $4 \%$ & & & \\
\hline & \multicolumn{10}{|c|}{ Defect location } \\
\hline & IAS & 2 & $4 \%$ & & & 2 & $4 \%$ & & & \\
\hline & EAS & 12 & $24 \%$ & & & 0 & $0 \%$ & & & \\
\hline & $\mathrm{IAS}+\mathrm{EAS}$ & 6 & $12 \%$ & & & 0 & $0 \%$ & & & \\
\hline
\end{tabular}

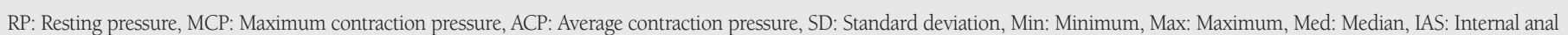
sphincter, EAS: External anal sphincter, Mann-Whitney U test, chi-square test was used 
existence and type of episiotomy, and birthweight were regarded as similar to those of the co-control groups. The premenopausal and postmenopausal anorectal manometric measurement data of women with vaginal deliveries were worse than women with c-sections (Table 6). During the course of our study, we observed that anal sphincter functions in post-vaginal delivery life were negatively affected regardless of the existence of FI symptoms. Furthermore, we ascertained that c-section had a protective effect both on OASIS and anal sphincter functions. Similarly, Hannah et al.(15) also reported that c-section proved to be protective for postpartum FI symptoms.

When we compared the results of the premenopausal groups, we saw that 20 (40\%) among the patients with vaginal delivery had occult anal sphincter injuries. When patients with vaginal deliveries were compared with the control group, there was no difference between FI symptoms and Wexner incontinence scores, although the former's mean maximum extrusion pressure was lower $(p>0.05)$. Studies in literature have reported that as EAUSG went into effect in medical practice, the rate of sphincter injuries reached $35 \%$ in primiparous women and $40 \%$ in multiparous women(16). Moreover, FI symptoms in these patients were observed less than sphincter injuries (13\% and 23\%, respectively)(17). Thus, some sphincter injuries formed during vaginal delivery do not result in FI. It is highly likely that remnant sphincter tissue is exposed to hypertrophy and enables the continuation of continence by increasing the amount of collagen in spite of the sphincter injury.

When the postmenopausal groups were compared, 44\%(22) of the vaginal delivery group had sphincter injuries. When the vaginal delivery group was compared with the control group, however, it was ascertained that the former had both worse manometric measurement results and significantly higher WIS ( $\mathrm{p}=0.03$; Table 5). Based on these data, it can be suggested that anal sphincter injuries that formed after vaginal delivery in the premenopausal stage remained occult but they proved to be a factor, which give way to an increase in FI symptoms in the postmenopausal stage. In contradiction to our results, Mous et al.(18) stated that the increase in FIs in the postmenopausal stage was related to postmenopausal disorders seen in the pelvic floor rather than sphincter injuries formed during vaginal delivery. With increasing age, and especially during the postmenopausal stage when estrogen in the body decreases, type 1 collagen tissue, which has thicker and stronger fibers, is replaced by type 3 collagen tissue, which has thinner, weaker, and isolated fibers. Moreover, IAS sclerosis develops with increasing age and atrophic changes take place in

Table 5. The comparison of demographic data, endoanal ultrasonography, and manometric measurement results of groups 2 and 4

\begin{tabular}{|c|c|c|c|c|c|c|c|c|c|c|}
\hline & & \multicolumn{4}{|c|}{ Group 2} & \multicolumn{4}{|c|}{ Group 4} & \multirow{2}{*}{$\mathrm{p}$} \\
\hline & & Mean \pm SD & n (\%) & Med & $(\operatorname{Min}$ - Max $)$ & Mean \pm SD & n (\%) & Med & (Min - Max) & \\
\hline Age & & $55.3 \pm 5.6$ & & 54 & $48-71$ & $55.7 \pm 5.5$ & & 56 & $41-64$ & 0.287 \\
\hline Delivery number & & $4.2 \pm 2.0$ & & 4 & $1-11$ & $2.2 \pm 0.8$ & & 2 & $1-4$ & $<0.001$ \\
\hline \multirow[t]{5}{*}{ Wexner score } & & $1.8 \pm 2.6$ & & 0 & $0-7$ & $0.4 \pm 1.0$ & & 0 & $0-3$ & 0.003 \\
\hline & 0 & 28 & & & & 40 & $80 \%$ & & & \\
\hline & $1-3$ & 10 & & & & 10 & $20 \%$ & & & \\
\hline & $4-5$ & 4 & & & & 0 & $0 \%$ & & & \\
\hline & $>6$ & 8 & & & & 0 & $0 \%$ & & & \\
\hline $\mathrm{RP}$ & & $49.2 \pm 16.4$ & & 45 & $22-77$ & $53.6 \pm 11.1$ & & 52 & $36-83$ & 0.140 \\
\hline $\mathrm{MCP}$ & & $137.0 \pm 43.0$ & & 131 & $57-221$ & $186.4 \pm 45.2$ & & 175 & $117-265$ & $<0.001$ \\
\hline Time & & $36.1 \pm 20.8$ & & 34 & $5-76$ & $73.5 \pm 26.2$ & & 72 & $38-148$ & $<0.001$ \\
\hline $\mathrm{ACP}$ & & $91.5 \pm 29.0$ & & 96 & $25-153$ & $144.8 \pm 39.8$ & & 132 & $81-217$ & $<0.001$ \\
\hline Gradient & & $68.8 \pm 138.2$ & & 28 & $2-691$ & $42.5 \pm 33.0$ & & 42 & $5-112$ & 0.348 \\
\hline \multirow{6}{*}{ Defect } & No & 28 & $56 \%$ & & & 48 & $96 \%$ & & & \multirow{2}{*}{$<0.001$} \\
\hline & Yes & 22 & $44 \%$ & & & 2 & $4 \%$ & & & \\
\hline & \multicolumn{10}{|c|}{ Defect location } \\
\hline & IAS & 4 & $8 \%$ & & & 2 & $4 \%$ & & & \\
\hline & EAS & 12 & $24 \%$ & & & 0 & $0 \%$ & & & \\
\hline & $\mathrm{IAS}+\mathrm{EAS}$ & 6 & $12 \%$ & & & 0 & $0 \%$ & & & \\
\hline
\end{tabular}

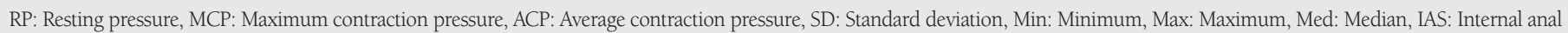
sphincter, EAS: External anal sphincter, Mann-Whitney U test, chi-square test was used 
the EAS and pelvic floor muscles with the decrease in estrogen as menopause begins(19). Furthermore, vaginal deliveries cause the pelvic diaphragm to move downward and give way to weakness in the pelvic floor(20). When all these mechanisms are taken into consideration, it is clear that bodily changes in the postmenopausal stage increase FI. The results of our study revealed that patients with vaginal deliveries had worse results in all anorectal manometric measurements and higher WIS compared with those in the co-control groups when we compared the results of postmenopausal patients with vaginal deliveries and c-sections. Therefore, we believe that occult anal sphincter injuries become symptomatic with pelvic floor disorders formed in the postmenopausal stage, and they bring about a further increase in the incidence of FI. Our results are in parallel with former studies; however, two previous studies that compared more than 15-year follow-up results of patients with FI with or without anal sphincter injury reported contradictory results $(21,22)$. Nygaard et al.(21) found no significant difference pertaining to FI between women with c-section delivery and those who had OASIS during normal delivery, and Faltin et al.(22) conducted a study with similar groups and the authors reported that OASIS had little contribution to FI. The results of our study revealed that women with vaginal deliveries had a higher rate of anal sphincter injury and had higher WIS and FI symptoms in the postmenopausal stage compared with women with c-section deliveries in the same stage. Previous studies in the literature stated that FI symptoms increased depending on many factors in the postmenopausal stage(20). The results of our study demonstrated that occult sphincter injury proved to be a significant factor that exacerbated these symptoms.

\section{Study Limitations}

One of the limitations of our study is that we did not conduct research on pudendal nerve damage. There is, however, controversy over the effect of pudendal nerve damage formed during vaginal delivery on FI formation(23). In a study by Sultan et al.(6) the authors found that $16 \%$ of primiparous women and $15 \%$ of multiparous women had long-term pudendal nerve terminal motor latency (PNTML) 6 weeks after vaginal delivery, but there was no relationship between PNTML change and the development of FI symptoms. Further, abnormal PNTML prolongation had a statistically significant relationship with anal sphincter injuries. The results of another study showed that only one third of prolonged PNTMLs 6 months after delivery

Table 6. Comparison of vaginal delivery groups' demographic, endoanal ultrasonography, and anorectal manometric data according to menopausal status

\begin{tabular}{|c|c|c|c|c|c|c|c|c|c|c|}
\hline & & \multicolumn{4}{|c|}{ Group 1} & \multicolumn{4}{|c|}{ Group 2} & \multirow{2}{*}{$\mathrm{p}$} \\
\hline & & Mean \pm SD & n (\%) & Med & $(\operatorname{Min}-\operatorname{Max})$ & Mean \pm SD & n (\%) & Med & (Min - Max) & \\
\hline \multicolumn{2}{|l|}{ Age } & $38.0 \pm 6.2$ & & 38 & $21-48$ & $55.3 \pm 5.6$ & & 54 & $48-71$ & $<0.001$ \\
\hline \multicolumn{2}{|c|}{ Delivery number } & $2.8 \pm 1.4$ & & 3 & $1-6$ & $4.2 \pm 2.0$ & & 4 & $1-11$ & $<0.001$ \\
\hline \multicolumn{2}{|c|}{ Wexner score } & $1.3 \pm 2.0$ & & 0 & $0-7$ & $1.8 \pm 2.6$ & & 0 & $0-7$ & 0.584 \\
\hline & 0 & 28 & $56 \%$ & & & 28 & $56 \%$ & & & \\
\hline & $1-3$ & 16 & $32 \%$ & & & 10 & $20 \%$ & & & \\
\hline & $4-5$ & 2 & $4 \%$ & & & 4 & $8 \%$ & & & \\
\hline & $>6$ & 4 & $8 \%$ & & & 8 & $16 \%$ & & & \\
\hline \multicolumn{2}{|l|}{$\mathrm{RP}$} & $53.1 \pm 20.7$ & & 52 & $23-95$ & $49.2 \pm 16.4$ & & 45 & $22-77$ & 0.327 \\
\hline \multicolumn{2}{|l|}{$\mathrm{MCP}$} & $163.8 \pm 46.6$ & & 167 & $91-268$ & $137.0 \pm 43.0$ & & 131 & $57-221$ & 0.004 \\
\hline \multicolumn{2}{|l|}{ Time } & $48.6 \pm 30.8$ & & 46 & $10-147$ & $36.1 \pm 20.8$ & & 34 & $5-76$ & 0.037 \\
\hline \multicolumn{2}{|l|}{$\mathrm{ACP}$} & $103.0 \pm 29.9$ & & 112 & $40-144$ & $91.5 \pm 29.0$ & & 96 & $25-153$ & 0.025 \\
\hline \multicolumn{2}{|c|}{ Gradient } & $334 \pm 40.1$ & & 15 & $1-153$ & $68.8 \pm 138.2$ & & 28 & $2-691$ & 0.181 \\
\hline \multirow{6}{*}{ Defect } & No & 30 & $60 \%$ & & & 28 & $56 \%$ & & & \multirow{2}{*}{0.685} \\
\hline & Yes & 20 & $40 \%$ & & & 22 & $44 \%$ & & & \\
\hline & \multicolumn{10}{|l|}{ Defect localization } \\
\hline & IAS & 2 & $4 \%$ & & & 4 & $8 \%$ & & & \\
\hline & EAS & 12 & $24 \%$ & & & 12 & $24 \%$ & & & \\
\hline & IAS + EAS & 6 & $12 \%$ & & & 6 & $12 \%$ & & & \\
\hline
\end{tabular}


remained pathological(24). Thus, we neglected to investigate the effects of pudendal nerve damage on FI in our study.

The other limitation of our study is that the participants in the pre- and postmenopausal groups were composed of different individuals. Pre- and postmenopausal data of participants in the same group could have rendered this study more significant. Instead, we selected participants with FI predisposing factors such as age, number of deliveries, BMI, birthweight, and instrument use to ensure similarity between the groups. This method of selection, in turn, contributed to the reliability of our study.

\section{Conclusion}

Vaginal deliveries prove to be one of the most significant causes that increase the rate of anal sphincter injuries. Anal sphincter injury formed subsequent to vaginal delivery can be an important factor which gives way to an increase in the incidence of postmenopausal FIs and the formation of FI symptoms in women.

\section{Ethics}

Ethics Committee Approval: The study was approved by the Necmettin Erbakan University, Meram Faculty of Medicine Local Ethics Committee (Approval number: 2013/79), Informed Consent: Consent form was filled out by all participants.

Peer-review: External and internal peer-reviewed.

\section{Authorship Contributions}

Surgical and Medical Practices: S.K., S.Ç., A.K., Concept: S.K., H.A., C.K., Design: S.K., M.Ç., Data Collection or Processing: S.K., S.Ç., A.K., Analysis or Interpretation: C.K., Literature Search: A.K., S.Ç., Writing: S.K.

Conflict of Interest: No conflict of interest was declared by the authors.

Financial Disclosure: The authors declared that this study received no financial support.

\section{References}

1. Wegnelius G, Hammarström M. Complete rupture of anal sphincter in primiparas: longterm effects and subsequent delivery. Acta Obstet Gynecol Scand 2011;90:258-63

2. de Leeuw JW, Struijk PC, Vierhout ME, Wallenburg HC. Risk factors for third degree perineal ruptures during delivery. BJOG 2001;108:383-7.

3. Mahony R, Behan M, O'Connell PR, O'Herlihy C. Effect of second vaginal delivery on anal function in patients at risk of occult anal sphincter injury after first forceps delivery. Dis Colon Rectum 2008;51:1361-6.

4. Oberwalder M, Connor J, Wexner SD. Meta-analysis to determine the incidence of obstetric anal sphincter damage. Br J Surg 2003;90:1333-7.

5. Evers EC, Blomquist JL, McDermott KC, Handa VL. Obstetrical anal sphincter laceration and anal incontinence 5-10 years after childbirth. Am J Obstet Gynecol 2012;207:425.el-6.

6. Sultan AH, Kamm MA, Hudson CN, Thomas JM, Bartram CI. Anal sphincter disruption during vaginal delivery. N Engl J Med 1993;329:1905-11.
7. Andrews V, Sultan A, Thakar R, Jones P. Occult anal sphincter injuries-myth or reality? BJOG 2006;113:195-200.

8. Sultan AH. Obstetric perineal injury and anal incontinence. Clin Risk 1999;5:193-6.

9. Franz HB, Wendler D, Oettling G. Immunohistochemical assessment of steroid hormone receptors in tissues of the anal canal. Implications for anal incontinence? Acta Obstet Gynecol Scand 1996;75:892-5.

10. Eogan M, O’Brien C, Daly L, Behan M, O'Connell PR, O'Herlihy C. The dual influences of age and obstetric history on fecal continence in parous women. Int J Gynaecol Obstet 2011;112:93-7.

11. Williams AB, Bartram CI, Halligan S, Marshall MM, Spencer JA, Nicholls RJ, et al. Alteration of anal sphincter morphology following vaginal delivery revealed by multiplanar anal endosonography. BJOG 2002;109:942-6.

12. Donnelly V, Fynes M, Campbell D, Johnson H, O'Connell PR, O'Herlihy C. Obstetric events leading to anal sphincter damage. Obstet Gynecol 1998;92:955-61.

13. Bo K, Finckenhagen HB. Vaginal palpation of pelvic floor muscle strength: inter-test reproducibility and comparison between palpation and vaginal squeeze pressure. Acta Obstet Gynecol Scand 2001;80:883-7.

14. Johnson JK, Lindow SW, Duthie GS. The prevalence of occult obstetric anal sphincter injury following childbirth-literature review. J Matern Fetal Neonatal Med 2007;20:547-54.

15. Hannah ME, Hannah WJ, Hodnett ED, Chalmers B, Kung R, Willan A, et al; Term Breech Trial 3-Month Follow-up Collaborative Group. Outcomes at 3 months after planned cesarean vs planned vaginal delivery for breech presentation at term: the international randomized Term Breech Trial. JAMA 2002;287:1822-31.

16. Sultan AH, Kamm MA, Bartram CI, Hudson CN. Anal sphincter trauma during instrumental delivery. Int J Gynaecol Obstet 1993:43:263-70.

17. Salman M, Özyüncü Ö, Durukan T. Gebelik, doğum ve pelvik taban bozuklukları. Türk Jinekoloji ve Obstetrik Derneği Dergisi 2005;2:37-42.

18. Mous M, Muller SA, de Leeuw JW. Long term effect of anal sphincter rupture during vaginal delivery: faecal incontinence and sexual complaints. BJOG 2008;115:234-8.

19. Klosterhalfen B, Offner F, Topf N, Vogel P, Mittermayer C. Sclerosis of the internal anal sphincter a process of aging. Dis Colon Rectum 1990;33:606-9.

20. Felt-Bersma RJ, Klinkenberg-Knol EC, Meuwissen SG. Anorectal function investigations in incontinent and continent patients. Dis Colon Rectum 1990;33:479-85.

21. Nygaard IE, Rao SS, Dawson JD. Anal incontinence after anal sphincter disruption: a 30-year retrospective cohort study. Obstet Gynecol 1997;89:896-901.

22. Faltin DL, Otero M, Petignat P, Sangalli MR, Floris LA, Boulvain M, et al. Women's health 18 years after rupture of the anal sphincter rupture during childbirth: I. Fecal incontinence. Am J Obstet Gynecol 2006;194:1255-9.

23. Oberwalder M, Dinnewitzer A, Baig MK, Thaler K, Cotman $\mathrm{K}$, Nogueras JJ, et al. The association between late onset fecal incontinence and obstetric anal sphincter defects. Arch Surg 2004;139:429-32.

24. Sultan AH, Kamm MA, Hudson CN. Pudendal nerve damage during labour: prospective study before and after childbirth. Br J Obstet Gynaecol 1994;101:22-8. 